\title{
Mobile Teachers at Border Schools - Multilingualism and Interculturalism as New Challenges for Professional Development
}

Katica Pevec Semec ${ }^{1}$

$\approx$ This article discusses the implementation of cross-border learning mobility, which has taken place in some schools and kindergartens at the tri-border area of Slovenia, Austria and Italy. The findings suggest that the implementation of multilingual and intercultural practices, which involve weekly exchanges of 'mobile teachers' from neighbouring countries, created a unique educational experience that has encouraged teachers to greater professional growth. In addition to another language, mobile teachers have brought with them various new educational approaches. Border mobility has contributed to the simultaneous strengthening and enriching of educational practices in various border kindergartens and schools. For teachers, the implementation of crossborder learning mobility strengthens the awareness of the importance of competence in multilingualism and interculturalism as an important factor for their further professional development. This article will analyse the knowledge and experience of professionals involved in such mobility programs in terms of a new dimension of professionalism, and the need to develop multilingualism and interculturalism competences.

Keywords: mobile teachers, neighbour language acquisition, multilingualism and interculturalism, professional development 


\section{Mobilni učitelji na obmejnih šolah - večjezičnost in medkulturnosti kot nov izziv za profesionalni razvoj}

Katica Pevec Semec

$\approx$ Članek se nanaša na nekatere ugotovitve pri izvajanju medregionalne vzgojno-izobraževalne prakse, ki je potekala v nekaterih vrtcih in šolah, ki so na tromeji med Slovenijo, Avstrijo in Italijo. Ugotovitve kažejo, da se je izvajanje večjezične in medkulturne prakse, ki so jo tedensko uresničevali učitelji iz sosednjih držav, t. i. mobilni učitelji, izoblikovalo v edinstveno pedagoško izkušnjo, ki je učitelje spodbudila k večji profesionalni rasti. Poleg novega drugega jezika sosednje države so mobilni učitelji prinašali v vrtce in šole tudi različne nove vzgojno-izobraževalne učne pristope. Predstavljena obmejna mobilnost učiteljev je hkrati prispevala $\mathrm{h}$ krepitvi in $\mathrm{k}$ obogatitvi vzgojno-izobraževalne prakse $\mathrm{v}$ različnih obmejnih vrtcih in šolah. Pri učiteljih je izvajanje čezmejne mobilnosti okrepilo zavedanje pomena usposobljenosti na področjih večjezičnosti in medkulturnosti kot pomembnega dejavnika njihovega profesionalnega razvoja. V članku so analizirana nekatera spoznanja in izkušnje strokovnih delavcev, vključenih v mobilnost, v katerih se izkazujeta nova dimenzija profesionalnosti ter potreba po razvoju večjezičnost in medkulturnosti.

Ključne besede: mobilni učitelji, učenje sosedskih jezikov, večjezičnost in večkulturnost, profesionalni razvoj 


\section{Introduction}

The learning and use of languages are fundamental to peaceful coexistence in the common European area, especially in those areas where languages and cultures have coexisted for centuries. In Slovenia, there is a long tradition of acknowledging the presence of the languages of neighbouring countries in the minority areas of Prekmurje and Istria. Moreover, it can be argued that these and other neighbouring languages (Croatian and German) are present in the area beyond the national borders, where there is urban proximity between the neighbouring countries: Slovenia, Austria and Italy. In elementary school, the neighbouring language is most often taught outside the compulsory curriculum, for example as an activity of interest to students. Therefore, the efforts of kindergartens (at the Kranjska Gora elementary school in Slovenia, at Camporosso in Italy, at Nötsch in Austria) and schools (Kranjska Gora Primary School, Volksschule Nötsch, Jesenice High School, Institutod'Istruzione Superiore Ingeborg Bachmann di Tarvisio) located on the triple border between Slovenia, Austria and Italy, with years of practical experience in the acquisition of neighbour languages and neighbour cultures, have particularly attracted our attention. Before the presentation of the project Comenius Regio Partnerships: Cooperation in the educational field between Italy and Slovenia (Co.E.S.I.) underpinning our discussion, we need to establish what is meant by, neighbour languages and neighbour cultures, multilingualism, and interculturalism and how these are reflected in the field of education. In addition, we will discuss several models for multilingual and intercultural education, including aspects of the professional development of teachers.

\section{Multilingualism and interculturalism as important as- pects of professional development}

In many aspects of our lives nowadays, there are requirements for effective communication as a consequence of globalisation and coexistence in a multicultural and multilingual society. The expanding need for multilingual and intercultural communication occurs as a result of mobility and the spread of market employability within the European Union and beyond and, consequently, migrations of people because of better material living conditions and the revitalisation of some provinces and regions. Globalisation additionally blurs the boundaries between countries, while economic markets are expanding beyond national borders. The rapid development of information and communication technology, which eliminates local distances and encourages simultaneous communication 
through various media, has also become an important factor. In the age of globalisation, we can add another fact ' [...] that today more people than ever live in a nearby neighbourhood with different languages and cultures, many of them working together or having daily encounters' (Wintersteiner, Gombos, \& Gronold, 2010, p. 28). People are thus becoming more mobile, for both private and professional reasons, and thus need to communicate in several languages. Knowledge of languages allows for intercultural dialogue and encourages the willingness to coexist along with mutual respect.

Neighbour languages and neighbour cultures (frontier languages) represent culturally marked opportunities for expression and are, therefore, an integral part of 'frontier policy' and can become both an instrument for demarcation or exclusion of countries, cultures and individuals and an occasion for encounter, contact and co-operation (Rasch, 2002, p. 18). Frontier regions are considered to have European characteristics and thus to represent potential areas for new approaches to learning and teaching (Beacco \& Byram, 2002 in Rasch, 2002, p. 5). We agree with the Rasch (2002, p .10), who stated that language teaching and learning can help in the promotion of relations between neighbouring countries in Europe.

Knowledge of languages allows for intercultural dialogue and encourages the willingness to coexist along with mutual respect.

Multilingualism is a complex phenomenon that can be studied from different perspectives in disciplines such as linguistics, psycholinguistics, sociolinguistics and education (Cenoz, 2013). Baker (1993) believed that the concept of bilingual education can refer not only to pupils who are already speakers of two languages, but also to those pupils who are studying two additional languages. Sometimes pupils who learn additional languages are also speakers of a dominant language in their society, which they learn as migrants or immigrants, and which is also taught as the dominant language at school (Baker, 1993).

Garcia (2009) pointed to the difference in education: namely, that bilingual education is different from traditional foreign language learning, where pupils learn the language as a subject, while in bilingual education the language is used as a medium for passing on instruction. Bilingual programs teach content through languages other than a pupil's first language (Garcia, 2009). Above all, the author highlights that bilingual education is a model that provides for meaningful, education, equivalent to general education, as well as training that builds tolerance for other linguistic and cultural groups.

Multilingual education is provided by general education, with teaching in two or more languages to develop a multi-dimensional understanding of the languages and cultures and to encourage acceptance of human diversity. 
According to Jazbec (2008), the original meaning of bilingualism in the Canadian and American contexts focuses on the integrative approach, where the primary focus is on the individual's competence in L2, which is being acquired and is in the process of becoming level L1 competence (Jazbec, 2008). Pižorn (2009) considered the term L2, which indicates those languages that are taught in a formal and non-language environment. These are characteristically used by children, predominantly in the school environment or in the media, but less commonly, in the home environment. Some authors, such as Wode (1995), claimed that L1 can be equated with the language in which individuals acquire increasingly genuine expression, one that also means belonging to a particular social group: that is, the language in which we dream and think.

For some authors, in the definition of multilingualism, the key difference lies between language competence and the use of a language. In this respect, Baker (2010) discussed functional bilingualism, which moves away from language skills and towards the use of language in everyday contexts and events. Functional bilingualism thus refers to when, where and with whom people use two languages (Fishman, 1965).

To summarise the work of Byram (2009), being bicultural or multicultural means accepting the beliefs and values of two or more different social groups and identifying with them. In so doing, someone who uses two or more languages and takes into account and analyses the similarities and differences between them can detect and analyse the similarities and differences between the values, beliefs, and behaviour of two or more groups to which they belong. In this case, such a person has the capacity for analytical use in practice, which involves coordination or mediation between distinct beliefs, values and behaviours. Such a person has the character of interculturalism with a focus on intercultural activities (Byram, 2009).

Below, we highlight some of the concepts of professional development for teachers that were used in the present case.

Several authors point out a number of aspects of professionalism: professional competence, i.e., the ability to perform given tasks in accordance with certain standards (Cummings \& Schwab in Cvetek, 2004); and the ability to think in action (Schon, 1983).

Numerous studies have dealt with the professional development of teachers, highlighting the ineffectiveness of programs because two key factors are not taken into account: what motivates teachers for participation and professional development, and the observance of the typical process in which change occurs (Guskey, 2002).

The teacher should have the opportunity to ask and support for asking 
questions such as why to change the existing working process, what to change and how, with whom to cooperate and how to tackle change. Ažman (2004) pointed out that teachers do this only in a school where similar questions are raised by other teachers, the school administration and other subsystems, while the social environment must also support and encourage such questioning.

It is essential in the creation of models of professional development that teachers in the process of lifelong learning give meaning to and develop their concepts as well as improve their teaching practice. This process relates to the fundamental task of a teacher, that is teaching, and includes their personal, professional and social dimensions, while also involving a progression towards a critical, independent, responsible, decision-making teacher (Valenčič Zuljan, 2001).

\section{Presentation of the project practices on the borders be- tween Slovenia, Austria and Italy - case studies}

In this section, we will focus on the presentation of the different practices of educational projects, which took place from 2003 to 2013 in the border area between Slovenia, Italy and Austria: Tri roke, Tre mani, Drei Hände (2006-2013); Ciao vicino, Živijo sosed, Servus Nachbar (2010-2013); Mrežno povezovanje Tri-krat-tri. Trojezično od vrtca do mature, Trilingually from kindergarten to matura/GCE (2012); Esco izobraževanje brez meja (2013). The presented practices were conducted through trilateral border cooperation between Slovenia, Italy, and Austria, as experimental work and Comenius Regio cooperation between Slovenia and Italy including the participants presented at the beginning of this paper.

The overall objective was to establish cooperation in the field of education and deepen learning about the languages and cultures of neighbouring countries and to include mobile teachers in the implementation of the official curriculum.

A further common feature of the practices was the motivation of the participants involved in the drafting and implementation of joint events, which had to include children/pupils/students. Comparison of the project practices shows that the differences lay in the intensity of the events, where there were either periodic meetings between practitioners and children/pupils/students from the border kindergartens and schools once or several times a year, or intensive one-week teaching practices, enriched with the neighbour languages and cultures.

It should be noted that the need for interregional project developments in learning the languages and culture of neighbouring countries is permanently 
present in the border area of Slovenia, Austria, and Italy. The differences are solely in how strongly the need for cooperation is supported on the local, regional and national levels and how they complement and reward each other.

During this period (2003-2013), there were also several meetings of professional staff, pupils, parents, principals, and other stakeholders. Teaching materials and the reflections of professional staff were presented at three conferences, with the participation of more than 300 colleagues from the three countries, together with representatives of faculties and universities in the countries involved.

The exploration of project practices in the field of education was qualitative in nature, mainly involving small groups of professionals, principals, and children and the external experts who have been planning and carrying out meetings, developing learning materials and evaluating the work. For research purposes, we developed and used a variety of instruments, such as the structured interview; we collected various data and documented cases of multilingual learning projects, recorded numerous cases of multilingual practices with students; we also developed educational materials and adapted them to the multilingual teaching practices. The core results are largely based on reflection, where some limitations to these practices become apparent, since the data collected was not intended for statistical processing.

Nonetheless, the users (teachers, professional staff, pupils, and principals) have recorded their reflections on the process of the implemented learning project examples. Their utility was tested for the relevant schools and kindergartens and upgraded with new experiences that occurred after the completion of the project.

Project findings are presented in full in a range of published materials, such as Esco-Educare senza confine-Bildung Ohne grenzen-Izobraževanje brez meja (2013); Pevec Semec, K. Poročilo projekta Commenius Regio: ItalijaSlovenija (2010-2013), Wintersteiner et al. (2010). Večjezičnost, transkulturnost in izobrazba.

We realise that we cannot address the entire border project operation from this period, because it is simply too extensive for our discussion. Therefore, our further analysis refers only to one of three regional projects undertaken on the borders between Slovenia, Austria and Italy so-called Comenius Regio partnership of Slovenia and Italy. 


\section{Specifics of the Comenius Regio project}

This project took place as a three-year project (2010-2013) between Italy and Slovenia to ensure continuity of cross-border cooperation between kindergartens and schools in Slovenia and Italy, while also including interested kindergartens and schools in Austria (Pevec Semec, 2013).

The Regio project upgraded the Tri roke, Tre mani, Drei Hände project's objectives in the direction of systematic implementation of multilingual teaching practice according to the CLIL methodology. The project involved local, mobile teachers. and school leaders (Kindergarten at Kranjska Gora Elementary School, Kindergarten Camporosso in Italy, Kindergarten in Nötsch in Austria, Kranjska Gora Primary School, Volksschule Nötsch, High School Jesenice, Institutod'Istruzione Superiore Ingeborg Bachmann di Tarvisio), faculty experts and representatives of the local community (University in Ljubljana, Maribor, Koper, Udine, Macerata and Higher Pedagogical School in Klagenfurt); coordination of the project was carried out by the National Education Institute Slovenia and the Regional Office of Friuli Venezia Giulia.

The project consisted of three-year cycles, comprising the following elements:

- Team meetings of practitioners (three times a year) included the creation of the annual project activity plan, the planning and implementation of reflection on lesson plans in three languages, the creation of didactic materials for the implementation of the lesson plans, the preparation for and implementation of the annual joint meetings of teachers and pupils, the monitoring and documentation of multilingual and intercultural learning practices;

- Meetings of school management and the project coordinator (twice a year) included the organisation of mobility and tackled the current implementation issues;

- Meetings of children, pupils, parents, teachers/educators, school management, representatives of the local community and other participants (once a year in different countries);

- Team monitoring of project activities such as the following: monitoring the implementation of multilingual and intercultural teaching practice; feedback collection from local and mobile teachers on their practical work; analysis of the annual reflections of project participants and analysis of participants' questionnaires at the end of the project.

In the first year, the focus was on organising weekly mobility, which 
included the preparation of mobile teachers for their work in Austria and Italy, and the preparation of local teachers to work with teachers arriving from Italy and Austria. In addition to the implementation of weekly mobility, teachers also selected a common theme at their meetings, according to which they prepared a learning project and carried it out in the three languages. Together with the students they collaborated in the development of didactic materials that were used at a joint meeting of students, teachers, and school leaders, and prepared a post-production video of teaching practice.

In the second year, local teachers, who conducted the regular curriculum in elementary schools in Slovenia, made proposals about the objectives and content of teaching for the school year. Mobile teachers become familiar with the proposals and ideas and chose how they themselves carried out their classes when teaching a certain theme. In the second year, local and mobile teachers again chose a common theme, prepared a project, and carried it out at a meeting with subsequent post-production video of teaching practice.

In the third year, the focus was on the preparation and presentation of the synthesis of knowledge in the implementation of multilingual and intercultural teaching practice, on the documentation of teaching materials, and on the final joint meeting of students and teachers, at which they again organised a post-production video of teaching practice.

The project was qualitative in nature; data mainly consisted of records of learning projects, students' educational materials and analyses of the annual reflections of the project participants. For the purposes of our article, we will hereafter focus only on the one aspect, i.e., the professional and personal development of teachers involved in border mobility, which represents the greatest achievement of the project.

\section{A model of professional development for 'teacher-direct- ed changes'}

The section below presents some of the key points of reflection, observed through three goals of professional development; it includes teachers' personal, professional and social dimensions, and constitutes a model of 'teacher-directed change'. Reflective activity was held twice during the project, in September 2012 and in July 2013 and included the following unfinished interview sentences: (I managed to ...; I enjoyed ...; It was hard for me ...; I could not ...; A great help to me was ...; Next time I will change ...; I would like to say ...). At the beginning and end of the project, we used the same type of interview instrument. This was followed by an analysis and categorisation of individual claims 
measured against the professional development targets. The specific objective was then examined in the light of the initial and final states. In this way, we reached conclusions about the three findings relating to all aspects of professional development, findings which represent the key results of our research.

The group consisted of home and mobile teachers from Slovenia (a total of 7 teachers).

\section{The first aspect of professional development: Change in the teaching practice of teachers}

The model builds on the foundation that change for teachers is essentially based on a process of experiential learning (Guskey, 2002). Local teachers noticed the most changes in the necessity for pre-planning and coordinating parts of lessons with the mobile teachers.

One of the mobile teachers described the change in her teaching practice, saying:

I managed to teach Slovene in neighbouring countries, improved my knowledge of German and started learning Italian, created a lot of didactic material for teaching Slovene as a foreign language, and learned to deal with a variety of situations that unexpectedly appear in the classes.

The data shed light on the conditions for the implementation of multilingual and intercultural teaching practice, which elicited several changes in the teaching practice of local teachers; they had to coordinate with other teachers outside their learning environment more than they usually did. In the act of coordination, they were exposed to both linguistic and professional challenges. The second part of the teacher's writing talks about a change in the preparation of didactic material for teaching Slovenian as a foreign language and, consequently, the need to improve language skills in foreign languages. The teacher also highlighted the skills for dealing with unforeseen learning situations.

\section{The second aspect of professional development: Changes in learning outcomes and student performance}

The measurement results do not relate to measurable achievements, but to the pupils' behaviour and attitude towards the subject, as well as his/her motivation.

The learning outcomes for pupils are broad-based, meaning that importance lies not only in cognitive and achievement-oriented learning but also in the pupils' behaviour and attitude (Guskey, 2002). These types of changes are reflected in the statements of local teachers, especially when they talk about what they managed to achieve: e.g., to motivate pupils for joint meetings; to 
prepare them to enjoy meetings with their teachers/educators; to collect ideas together with pupils and successfully implement these at joint meetings.

I enjoyed watching their optimism, enthusiasm, love of work, expectations, when I caught them in a spontaneous conversation with their peers from Italy or Austria. I liked that the work was interdisciplinary. (Local teacher)

You feel good when these children accept you among themselves, are happy when they meet you and are highly motivated to learn the Slovenian language. (Mobile teacher)

These statements highlight some of the psychological and social aspects of a supportive learning environment, aspects which significantly affect the learning achievement of children.

This is confirmed in the following statements:

Such learning that takes place across borders and the project itself are priceless. Students have a wider view of the world, are able to adapt to situations, and are more successful at their school work (Local teacher).

During the school year, I have noticed great progress in the understanding and perception of learning Slovenian. At the beginning students were often embarrassed by their incomprehension; however, later they became much calmer, motivated for work and confident in communicating in a foreign language. How interesting it is to observe children using three languages in a conversation (Mobile teacher).

\section{The Third aspect of professional development: A change in the teacher's beliefs and attitudes}

Learning to control something new, find it meaningful and try it in a new way requires time and effort. Each and everything that promises to increase teacher/educator competences and improve pupils' results means additional work, especially at the beginning. This requires additional time and energy, which leads to additional workload for the teachers. (Guskey, 2002).

Even after the second year of the project, the majority of teachers found it difficult to reconcile school work with project work.

I have worked a lot in my spare time. There have been many such hours. Everything cannot be done at school (Local teacher).

One mobile teacher indicated that transport and support for the implementation of multilingual practices in the neighbouring country were quite 
strenuous: 'It was hard driving in winter conditions and having lessons in Italy without an additional teacher in the class, totally on my own.'

In common with practitioners in many other fields, the teachers do not want to adopt a new practice or procedure until they have a sense that it works: In the years of work in the 'Tri roke, Tre mani, Drei Hände' and 'ŽivjoServus-Ciao' projects, the quality of my work in the classroom improved drastically. Working with students older than 12, I have come to the significant conclusion that success and progress are the direct result of good intrinsic motivation in students. Students needed to sense the meaning in language learning and its practical use, and I had to use all my senses and movement in teaching (Local Teacher).

Implementing change or trying something new also implies the risk of failure (Bolster, 1983).

I could briefly describe the project as: Three countries, three languages, three cultures, three different school systems, curious, openhearted and motivated children, friendly, helpful and positive teachers, a lot of timeconsuming preparation, the high quality of lessons in Slovene, laughter, good relationships and satisfaction on the part of the children (Mobile teacher).

\section{Conclusion}

Plurilingualism is gradually gaining ground at the European Council in the field of learning foreign languages. Plurilingualism is not a separation between languages but the construction of communicative skills, which contribute to the overall knowledge and experience of language. In this article, we have focused on the presentation of the promotion of multilingualism in the educational systems of the three countries and three neighbouring languages: Slovenian, German and Italian and of the three cultures that coexist in the geographic area between the region of Gorenjska (Upper Carniola), Carinthia and Friuli-Venezia Giulia.

Despite some weaknesses in methodology, the presented model for border mobility among professional staff can highlight some key elements arising from this model:

- The inter-regional cooperation in the field of education follows the European guidelines for the development of multilingualism and interculturalism in the direction of achieving the $\mathrm{M}+2$ norm.

- The concept of teacher mobility is unique. Mobile teachers as native 
speakers are also carriers of culture and of national and other features that promote linguistic spontaneity and authenticity.

- Teachers and students have a common goal: the development of language and cultural awareness. A student will develop their awareness through the recognition of one or more mutual factors, whereas a teacher/ educator will motivate students for the recognition of cultural consciousness (Swain \& Johnson in Baker, 2010).

- The implementation of educational practice involving mobile teachers enriches the existing curriculum with the coexistence of different languages, cultures and educational and methodological approaches to teaching. Thus, it encourages professional growth in both mobile and local teachers. In the course of their work, mobile teachers get to know their personalities, share and update their teaching practice and build on the expertise and skills as well as language and culture of neighbouring countries. Here involving Slavic, Germanic and Romance cultures.

- The uniqueness of this model lies in its combination of both personal and territorial multilingualism in the new format, which, according to Jazbec (2013), does not yet have a name, but is multi-dimensional in character.

The model of education presented in this article was conducted as research into multilingual education. Many important steps have been made, which may lead to the formalisation of its implementation in the educational systems of the three countries. The model pointed out new aspects of professionalism among the professional staff that will need to be explored further in the direction of professional capital. The role of mobile teachers in educational practice presented in this article could constitute a further challenge for those faculties that educate future teachers.

Raasch (2002) points out that the frontier regions offer many new opportunities in which the values of plurilingualism become more visible and can be implemented more rapidly. We hope that this article, with its focus on the mobility of teachers, will serve as such a model for cross-border cooperation in the field of education and contribute to the consideration of borders between countries and, within our minds, becoming more permeable; for children who are educated in the border area, it is important that meeting people from neighbouring countries who speak a completely different language be accepted as an everyday situation and that children use their language and other skills to make their way towards neighbouring languages (Gombos, 2013). 


\section{References}

Ažman, T. (2004). Profesionalni položaj in razvoj učitelja v sodobni šoli: dileme in perspektive [Professional position and development of a teacher in a modern school: Dilemmas and perspectives]. Sodobna pedagogika, 55(special edition), 220-235.

Baker, C. (1993). Bilingual education in Wales. In H. Baetens Beardsmore (Ed.), European typologies of bilingual education. Clevedon, UK: Multilingual Matters.

Baker, C. (2010). Foundations of bilingual education and bilingualism (4th ed.). Bristol, UK: Multilingual Matters.

Byram, M. (2009). Jezikovno izobraževanje za plurilingvistične in medkulturne učence. In K. Pižorn (Ed.), Učenje in poučevanje dodatnih jezikov v otroštvu [Learning and teaching extra languages in childhood] (pp. 116-135). Ljubljana: Zavod RS za šolstvo.

Cenoz, J. (2013). Defining multilingualism. Annual Review of Applied Linguistics, 33, 3-18.

Cvetek, S. (2004). Kompetence v poučevanju in izobraževanju učiteljev [Competencies in teaching and teacher education]. Sodobna pedagogika, 55(special edition), 144-161.

Esco-Educare senza confine-Bildung Ohne grenzen-Izobraževanje brez meja (2013). [Education without borders]. Gorizia: Grafica Goriziana.

Fishman, J. A. (1965). Who speaks what language to whom and when? La Linguistique, 2, 67-68.

Garcia, O. (2009). Bilingual education in the 21st century. A global perspective with contributions by Hugo Beatems Beardsmore. Singapore: Utopia Press Pte ltd.

Gombos, G. (2013). Analiza intervjujev vključenih udeležencev projekta Regio SLO-ITA. Delovno gradivo. [Analysis of the interviews of the involved participants of the Regio SLO-ITA project. Working material.]. Ljubljana: Zavod za šolstvo.

Guskey, T. R. (2002). Professional Development and Teacher Change. Teacher and Teaching, 8(3), 381-391. Jazbec, S. (2008). Sporazumevanjev tujih jezikih - Uvajanje tujega jezika in medkulturnega/medjezikovnega uzaveščanja v 1. VIO v OŠ: Teoretična razmišljanja [Communication in foreign languages - Introduction of a foreign language and intercultural / interlingual awareness in the 1st VIO in the elementary school]. Retrieved from http://www.zrss.si/projektiess/skladisce/sporazumevanje_v_tujih_jezikih/tuj\%2O jezik\%20v\%2oprvem\%2otriletju/Strokovni\%20\%C4\%8Dlanki\%2oin\%2oprevodi/projekt_zgodnje_ ucenje_sasa_jazbec_28_08.2008.pdf

Jazbec, S. (2013). Večjezičnost - nov vidik za učiteljev profesionalni razvoj. Predstavljeno na mednarodnem posvetu: Kompetence brez meja [Multilingualism - a new aspect for teachers' professional development. Presented at the international conference: Competence without borders]. Lignano: Zavod za šolstvo. Mrežno povezovanje Tri-krat - tri (2012). Networking Three times - three. On the way to cross-secondary education in Austria, Italy, Slovenia. Retrieved from http://www.dreitretri.eu/index.php/de/wp3-2 Na poti do čezmejnega sekundarnega izobraževanja za Avstrijo, Italijo, Slovenijo. E.S.C.O. Izobraževanje brez meja. (2013). On the way to cross-border secondary education for Austria, Italy, Slovenia. E.S.C.O. Education without borders. Regione Autonoma Friuli Venezia Giulia. Goriziana.

Pevec Semec, K. (2013). Poročilo projekta Comenius Regio: Italija-Slovenija (2010-2013). [Comenius Regio 
project report: Italy-Slovenia 2010-2013]. Working material.

Pevec Semec, K. (2012). Trojezično poučevanje: primeri iz različnih projektov. Presented at the conference: Poti do čezmejnega večjezičnega izobraževanja med Italijo, Avstrijo in Slovenijo [Trilingual teaching: examples from different projects. Presented at the conference: Paths to cross-border multilingual education between Italy, Austria and Slovenia]. Videm: Zavod za šolstvo.

Pižorn, K. (2009). Učenje in poučevanje dodatnih jezikov v otroštvu. [Learning and teaching extra languages in childhood]. Ljubljana: Zavod RS za šolstvo.

Rasch, A. (2002). Europe, frontiers and languages. Guide for the development of language educational policies in Europe. From linguistic diversity to plurilingual education. Strasbourg: Council of Europe.

Schon, D. (1993). The reflective practitioner. New York, NY: Basic Books.

Valenčič Zuljan, M. (2001). Pojmovanja znanja pri bodočih učiteljih [Knowledge of future teachers].

Andragoška spoznanja, 7(2), 16-23.

Wintersteiner, W., Gombos, G., \& Gronoland, D. (2010). Večjezičnost, transkulturnost in izobrazba [Multilingualism, transculturally and education]. Goriziana: Wieser.

Wode, H. (1995). Lernen in der Fremdsprache: Grundzüge von Immersion und bilingualem Unterricht. [Learning in the foreign language: basic features of immersion and bilingual teaching]. Ismaning: Max Hueber Verlag.

\section{Biographical note}

Katica Pevec Semec, PhD, is employed at the National Institute of Education in Ljubljana. She is a pedagogical advisor for the field of nationality education in Slovenia. She took her doctoral degree in the field of pedagogy and Foreign Languages; her doctorate was titled Multilingualism and interculturalism as professional capital: the making of a model of teacher education in primary schools in border areas. Her bibliography consists of more than 70 units. She is the authoress of books, authoress of scientific and professional articles from the field of education, multiligualism, learning and teaching foreign languages in early and middle childhood; multisensory learning and teaching foreign languages; bearer and implementer of foreign and domestic research projects, projects of the European Social Fund and Comenius Regio projects. 